To Maega | Jurnal Pengabdian Masyarakat

Februari 2022, Vol.5, No.1, hal, 114-122

$\operatorname{ISSN}(P): 2622-6332 ; \operatorname{ISSN}(E): 2622-6340$

http://www.ojs.unanda.ac.id/index.php/tomaega

\title{
Penyuluhan Analisis Usaha Tani Jagung Kelurahan Sombalabella, Takalar
}

\author{
Nurul Mukhlishah ${ }^{1 *}$, Darmawan Risal 2, Rahmawati ${ }^{3}$, Andi Hafidah 4 \\ ${ }^{1}$ Program Studi Teknik Pertanian, Fakultas Pertanian, Universitas Indonesia Timur \\ 2 Program Studi Kehutanan, Fakultas Pertanian, Universitas Indonesia Timur \\ 3 Program Studi Farmasi, Fakultas Farmasi, Universitas Indonesia Timur \\ ${ }^{4}$ Program Studi Manajemen, Fakultas Ekonomi, Universitas Indonesia Timur
}

*Correspondent Email: nurulmukhlishah@rocketmail.com

\author{
Article History:
}

Received: 20-12-2021; Received in Revised: 26-12-2021; Accepted: 11-01-2022

DOI: http://dx.doi.org/10.35914/tomaega.v5i1.970

\begin{abstract}
Abstrak
Kabupaten Takalar merupakan salah satu sentra penghasil jagung di Sulawesi Selatan. Perkembangan hasil produksi selama rentang waktu 2015-2019 menunjukkan produksi jagung di Kabupaten Takalar yang terus meningkat. Salah satu kendala petani jagung di Kelurahan Sombalabella, Kabupaten Takalar adalah petani belum mengetahui bagaimana cara menghitung analisis usaha tani, hal ini menyebabkan petani belum paham apakah usaha tani membawa keuntungan, impas, atau rugi. Kegiatan dilakukan pada hari Sabtu, 9 Oktober 2021 berlokasi di Kelurahan Sombalabella, Kecamatan Pattallasang, Kabupaten Takalar. Metode pelaksanaannya yaitu pelatihan penggunaan mesin pasca panen dan penyuluhan analisis usaha tani. Kegiatan ini dihadiri oleh petani jagung sebanyak 40 orang dari Kelompok Tani Sompu dan Kelompok Tani Biring Je'ne. Hasil dari kegiatan adalah penyerahan mesin multi fungsi untuk memipil, mencacah jagung, dan membuat tepung pakan dari limbah jagung serta memberikan pemahaman baru bagi petani terkait analisis usaha tani. Petani bisa membedakan biaya variable dan biaya tetap, petani bisa membedakan penerimaan dan pendapatan, petani mengetahui apakah usaha taninya layak atau tidak. Berdasarkan hasil analisis data diketahui terjadi peningkatan pengetahuan analisis usaha tani.
\end{abstract}

Kata Kunci: Penyuluhan, Analisis, Usaha Tani, Jagung

\begin{abstract}
Takalar Regency is one of the centers of corn production in South Sulawesi. The development of production results during the 2015-2019 period shows that corn production in Takalar Regency continues to increase. One of the obstacles for corn farmers in Sombalabella Village, Takalar Regency is that farmers don't know how to calculate farming business analysis, so that farmers don't know whether farming brings profit, break even, or loss. The activity was carried out on Saturday, October 9, 2021, located in Sombalabella Village, Pattallasang District, Takalar Regency. The implementation method is training on the use of post-harvest machines and counseling on farming analysis. This activity was attended by 40 corn farmers from Sompu Farmers Group and Biring Je'ne Farmers Group. The results of the activity is delivery multifunction machines for shelling, chopping corn, and making feed flour from corn waste and provide a new understanding for farmers about farming analysis. Farmers can distinguish between variable costs and fixed costs, farmers can distinguish between
\end{abstract}


income and income, farmers know whether their farming business is feasible or not. Based on the results of data analysis, there is an increase in knowledge of farming analysis.

Key Word: Extension, Analysis, Farming, Corn

\section{Pendahuluan}

Indonesia dikenal sebagai negara agraris yang mengandalkan sektor pertanian sebagai mata pencaharian dan sebagai penopang pembangunan. Sektor pertanian menopang ekonomi Indonesia karena pertanian membentuk proporsi yang sangat besar memberikan sumbangan untuk kas pemerintah. Hal ini menjadikan sektor pertanian sebagai pasar yang potensial untuk produk dalam negeri baik untuk barang produksi maupun barang konsumsi, terutama produk yang dihasilkan oleh sub sektor tanaman pangan (Berliana, 2010).

Salah satu komoditas pangan yang memiliki arti penting adalah jagung (Zea Mays L). Jagung merupakan salah satu bahan pangan penting karena merupakan sumber karbohidrat penting kedua setelah beras di Indonesia. Sumber daya Indonesia sangat mendukung untuk budidaya tanaman jagung, harga relatif murah, dan tersedia teknologi budidaya hingga pengolahan (Mukhlis \& Suyono, 2013).

Perkembangan luas tanam jagung di Sulawesi Selatan terus meningkat dari tahun ke tahun. Berdasarkan laporan Pusat Data dan Sistem Informasi (Pusdatin) Kementan luas panen jagung di Sulawesi Selatan 377,7 ribu hektar yang menghasilkan 1,82 juta ton jagung. Kabupaten Takalar merupakan salah satu sentra penghasil jagung di Sulawesi Selatan. Perkembangan hasil produksi selama rentang waktu 2015-2019 menunjukkan produksi jagung di Kabupaten Takalar yang terus meningkat.

Tabel 1. Jumlah Produksi dan Luas Panen Tanaman Jagung di Kabupaten

Takalar

\begin{tabular}{|r|r|r|r|r|}
\hline \multicolumn{1}{|c|}{ Tahun } & \multicolumn{1}{c|}{$\begin{array}{c}\text { Jumlah } \\
\text { Produksi } \\
\text { (Ton) }\end{array}$} & \multicolumn{1}{|c|}{$\begin{array}{c}\text { Persentase } \\
\text { \% }\end{array}$} & \multicolumn{1}{c|}{$\begin{array}{c}\text { Luas Panen } \\
\text { (Ha) }\end{array}$} & \multicolumn{1}{c|}{$\begin{array}{c}\text { Persentase } \\
\text { \% }\end{array}$} \\
\hline 2015 & 18.015 & 6,34 & 3.923 & 8,59 \\
\hline 2016 & 46.308 & 16,31 & 6.904 & 15,11 \\
\hline 2017 & 55.973 & 19,72 & 9.208 & 20,16 \\
\hline 2018 & 69.710 & 24,55 & 11.922 & 26,10 \\
\hline 2019 & 93.891 & 33,08 & $13.704,5$ & 30,04 \\
\hline Total & 283.897 & 100 & $45.661,5$ & 100 \\
\hline
\end{tabular}

Sumber: Dinas Tanaman Pangan, Holtikultura, Perkebunan, Sul-Sel, 2020

Berdasarkan Tabel 1 diketahui tanaman jagung dari tahun ke tahun mengalami peningkatan. Dari tahun 2018 ke 2019 mengalami peningkatan $8.53 \%$. Peningkatan produksi selayaknya menjadikan komoditas jagung sebagai 
komoditas unggulan sektor pertanian Kabupaten Takalar. Jika tingkat produktivitas jagung semakin meningkat, tentu akan meningkatkan pendapatan serta kesejahteraan petani.

Peningkatan keuntungan diharapkan berdampak pada peningkatan kehidupan ekonomi keluarga menjadi lebih baik. Dalam mencapai tujuan tersebut, petani selalu memperhitungkan untung ruginya walaupun tidak secara tertulis (Athaillah, 2020). Petani dalam melakukan usaha tani, berperan sebagai pemilik dan tenaga kerja utama, petani juga berperan sebagai pengelola atau manajer. Tujuan utama petani melakukan usaha tani adalah mendapatkan keuntungan dari usaha tani dan mendapatkan kesejahteraan keluarga. Untuk mengetahui apakah usaha yang dijalankan oleh petani mengalami keutungan atau tidak diperlukan adanya analisis kelayakan usaha tani. Analisis kelayakan adalah upaya untuk mengetahui tingkat kelayakan atau kepantasan dari suatu jenis usaha, dengan melihat beberapa parameter atau kriteria kelayakan tertentu.

Pengukuran kelayakan usaha tani dipengaruhi oleh biaya tetap (fixed cost) dan biaya tidak tetap (variable cost). Besarnya biaya tetap tidak tergantung pada besar kecilnya produksi yang diperoleh. Misalnya biaya pajak yang akan tetap dibayar walaupun usaha tani itu besar atau gagal sekalipun. Beberapa faktor produksi yang dapat mempengaruhi tinggi rendahnya produksi meliputi; luas lahan yang dimilki, jumlah benih yang digunakan, jumlah tenaga kerja yang digunakan, banyaknya pupuk yang digunakan, banyaknya pestisida yang digunakan, keadaan pengairan, tingkat pengetahuan dan keterampilan, tingkat kesuburan tanah, iklim atau musim, modal yang tersedia (Soekartawi, 2005).

Penerimaan merupakan hasil kali produksi yang dikalikan dengan harga jual yang merupakan hasil kotor dari usahatani sebelum dikurangi biaya-biaya untuk proses produksi (Damayanti \& Herdian, 2016). Penerimaan usahatani juga dipengaruhi oleh beberapa faktor seperti luas usahatani, jenis, dan harga komoditi usahatani yang diusahakan (Sundari, 2011). Selanjutnya menurut Harmono dan Andoko (2005) ratio penerimaan atas biaya (R/C ratio) menunjukkan berapa besar penerimaan yang akan diperoleh dari setiap rupiah yang dikeluarkan dalam produksi usaha, dari angka rasio penerimaan atas biaya tersebut dapat diketahui apakah usaha tersebut menguntungkan atau tidak. Pilihan yang paling penting dilakukan oleh petani adalah bagaimana memperoleh rasio yang cukup lebar antara pendapatan yang diperoleh dari kegiatan usahataninya bila dibandingkan dengan total biaya produksi yang telah dikeluarkan. Semakin besar rasio yang didapat maka semakin tepat pilihan penggunaan sumberdaya yang dilakukan dalam kegiatan usahatani (Normansyah dkk, 2014).

Penggunaan teknologi sangat diperlukan untuk mendukung kegiatan panen jagung, terutama untuk meningkatkan produktivitas jagung. Teknologi mesin pemipil jagung dimiliki oleh pedagang sehingga mengharuskan petani mengeluarkan biaya pemipilan sebesar Rp. 70/Kg (Risal \& Rahmawati, 2021). Hal ini mempengaruhi biaya tidak tetap (variable cost). Sehingga, salah satu 
masalah yang dihadapi petani adalah belum tersedianya mesin pasca panen jagung.

Kendala lain adalah petani jagung di Kelurahan Sombalabella belum mengetahui bagaimana cara menghitung analisis usaha tani, hal ini menyebabkan petani belum paham apakah usaha tani membawa keuntungan, impas, atau rugi. Keadaan ini disebabkan oleh pengetahuan mengenai analisis usaha tani yang masih rendah. Sehingga dibutuhkan suatu kegiatan untuk memberikan materi terkait dengan analisis usaha tani. Hasil luaran yang diharapkan dari kegiatan ini adalah petani mampu menghitung $\mathrm{R} / \mathrm{C}$ rasio usaha taninya dalam setiap musim.

\section{Metode}

Kegiatan penyuluhan dilakukan pada hari Sabtu, 9 Oktober 2021 berlokasi di Kelurahan Sombalabella, Kecamatan Pattallasang, Kabupaten Takalar. Kegiatan ini dihadiri oleh petani jagung sebanyak 40 orang dari Kelompok Tani Sompu dan Kelompok Tani Biring Je'ne. Petani yang mengikuti kegiatan adalah petani yang aktif membudidayakan tanaman jagung. Petani juga memadukan kegiatan bertani dan berternak sapi dan ayam. Kegiatan ini juga dihadiri oleh Wakil Rektor 4 Universitas Indonesia Timur, Ketua LPPM Universitas Indonesia Timur, Kepala BPP Kecamatan Pattallasang, PPL Kecamatan Pattallasang, dan Sekretaris Dinas Pertanian Kabupaten Takar.

Tahapan kegiatan:

1. Persiapan

Silaturahmi ke Ketua Kelompok Tani Bapak Abdul Wahid yang didampingi oleh Ibu penyuluh pertanian setempat. Melalui pertemuan tersebut, kami menyampaikan dan mengutarakan beberapa target dan luaran yang akan dicapai melalui penyuluhan ini. Kemudian diskusi berlanjut membahas masalah mengenai analisis usaha tani yang belum dilaksanakan oleh anggota kelompok tani.

Tahapan selanjutnya adalah meminta izin kepada pemerintah Kabupaten Takalar untuk melaksanakan kegiatan penyuluhan. Pada kesempatan ini kami juga menyampaikan target dan luaran dari kegiatan ini. Sehingga pemerintah Kabupaten Takalar menyambut positif rencana dari pelaksanaan kegiatan ini.

2. Pelaksanaan

a. Pelatihan penggunaan mesin pasca panen

Pelatihan menggunakan mesin multi fungsi untuk memipil, mencacah jagung, dan membuat tepung pakan dari limbah jagung.

b. Penyuluhan analisis usaha tani

Kegiatan dilanjutkan dengan menyampaikan materi analisis usaha tani. Materi berisi tentang biaya variable, biaya tetap, biaya produksi, biaya penyusutan alat, penerimaan, pendapatan, dan $\mathrm{R} / \mathrm{C}$ rasio. 
3. Monitoring dan Evaluasi

Setelah pelaksanaan kegiatan, tahapan selanjutnya adalah monitoring dan evaluasi.

4. Pengolahan data

Pengolahan data menggunakan pendekatan Skala Likert Summated Rating Scale (LSRS) dengan menggunakan skala 1 - 5 dari kategori sangat kurang hingga sangat mengetahui.

\section{Hasil dan Pembahasan}

Kelompok tani mitra yang menjadi objek penyuluhan adalah kelompok tani Biring Je'ne dan kelompok tani Sompu yang berada di Kecamatan Pattallasang Kabupaten Takalar.

Tabel 2. Uraian Kegiatan

\begin{tabular}{|l|l|l|}
\hline No. & Uraian Kegiatan & Keterangan \\
\hline 1. & Pelatihan penggunaan mesin pasca panen & Berhasil \\
\hline 2. & Penyuluhan analisis usaha tani & Berhasil \\
\hline
\end{tabular}

Mesin pasca panen yang diberikan merupakan kombinasi dari tiga operasi yang berbeda, yaitu memipil jagung, memecah jagung, dan mengolah limbah jagung menjadi produk pakan ternak dalam bentuk tepung yang dijadikan satu rangkaian operasi sehingga lebih cepat dan efisien. Keunggulan mesin ini adalah multi fungsi, satu mesin mampu memipil, memecah, dan menghancurkan limbah menjadi tepung. Sehingga, waktu yang dibutuhkan untuk proses pasca panen jagung lebih singkat.
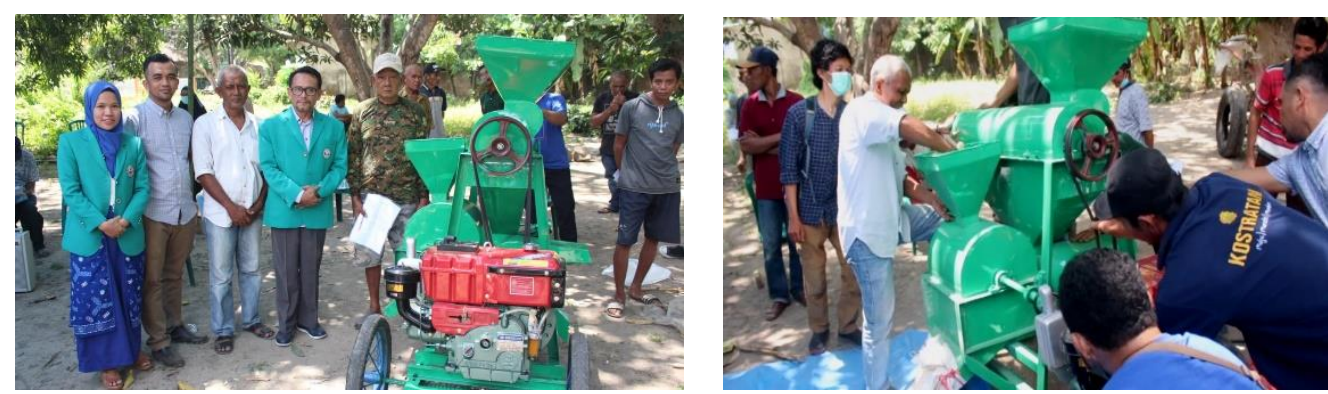

Gambar 1. Penyerahan dan pelatihan penggunaan mesin kepada Kelompok Tani Sompu dan Kelompok Tani Biring Je'ne

Masuknya mesin pipil pecah jagung bisa membantu petani meminimalisir biaya pasca panen karena sebelum adanya mesin pipil pecah petani memipil dan memecah jagung pada pedagang. Pada saat sosialisasi nampak bahwa para petani sangat antusias mengadopsi teknologi mesin pipil pecah tersebut. Penggunaan mesin ini dinilai lebih praktis dan efisien. Mesin ini juga mampu mengubah limbah jagung menjadi tepung untuk pakan ternak. Mesin ini mampu mengubah 
kebiasaan petani, sebelumnya petani hanya membuang atau membakar limbah hasil pertanian, sekarang petani mampu mengolahnya menjadi pakan ternak.

Teknologi mesin menggeser aktivitas pertanian dan aktivitas sosial para petani. Setelah adanya mesin pipil pecah, para petani bisa melakukan memipil dan memecah jagung di dalam kelompok taninya, tidak perlu lagi membayar ke pedagang untuk memipil dan memecah jagung.

Penggunaan alat atau mesin modern juga dapat mengefesienkan waktu ataupun mengurangi jumlah tenaga kerja dibandingkan dengan sistem pertanian tradisional yang menggunakan banyak tenaga kerja dan menghabiskan waktu yang lama untuk menyelesaikan pekerjaan pertanian (Jaya, 2016). Pengembangan alat dan mesin pertanian juga akan berperan untuk meningkatkan produktivitas dan efisiensi, menekan kehilangan hasil, dan meningkatkan mutu hasil (Umar, 2011).
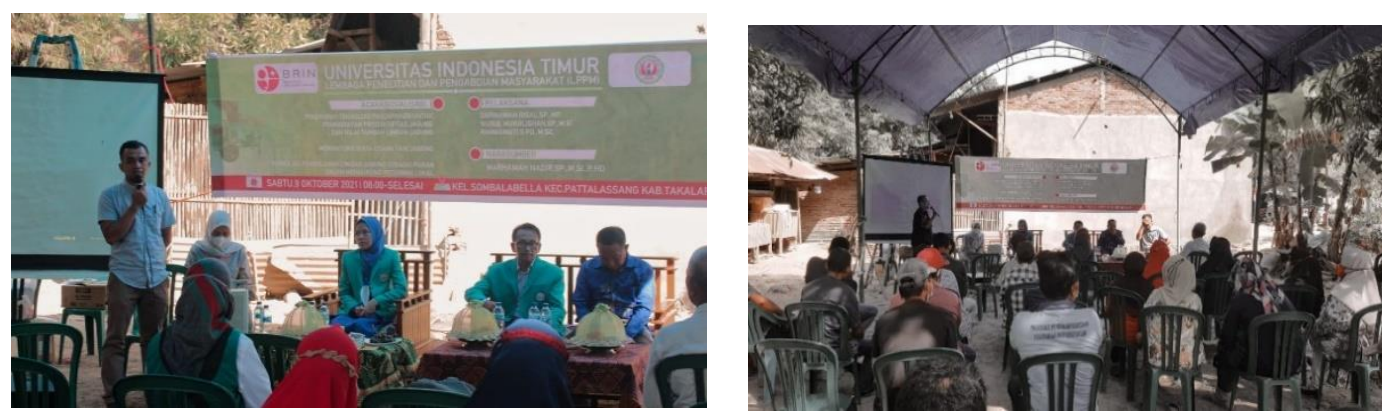

Gambar 2. Penyuluhan kepada Kelompok Tani Sompu dan Kelompok Tani Biring Je'ne

Biaya usaha tani jagung dibagi 2 bagian yaitu biaya tetap dan biaya variable. Biaya tetap meliputi biaya penyusutan alat dan sewa lahan. Biaya variable meliputi biaya benih, pupuk, pestisida dan tenaga kerja. Besarnya biaya tetap jagung berdasarkan salah satu anggota kelompok tani adalah sebesar Rp. 1.040.000,- dan biaya variable adalah sebesar Rp. 7.875.000,-. Sehingga biaya total usaha tani jagung dalam satu kali proses produksi adalah sebesar Rp. 8.915.000,-.

Jumlah hasil panen jagung per satu kali proses produksi adalah $5.000 \mathrm{Kg}$, dengan harga jual Rp. 3.500,- per kilogram. Penerimaan diperoleh dengan cara perkalian antara hasil produksi dan harga dari produksi (Sari, dkk 2018). Maka penerimaan usaha tani jagung per satu kali proses produksi adalah $5.000 \mathrm{Kg} \mathrm{x}$ Rp. 3.500,- sehingga penerimaan usaha tani jagung adalah Rp. 17.500.000,-. Pendapatan adalah selisih antara penerimaan dengan biaya total. Sehingga pendapatan dari usaha tani jagung per satu kali proses produksi adalah Rp. 8.585.000,-. Analisis R/C rasio adalah perbandingan antara penerimaan dengan biaya produksi, sehingga diketahui analisis $\mathrm{R} / \mathrm{C}$ rasio usaha tani jagung 
adalah 1.9. Artinya setiap Rp. 1,- biaya yang dikeluarkan akan memperoleh nilai penerimaan sebesar Rp. 1.9,--

Selanjutnya dilakukan pengukuran peningkatan pengetahuan dengan menggunakan kuesioner skala likert. Berikut hasil analisis tingkat pengetahuan mitra petani mengenai analisis usaha tani Gambar 3.

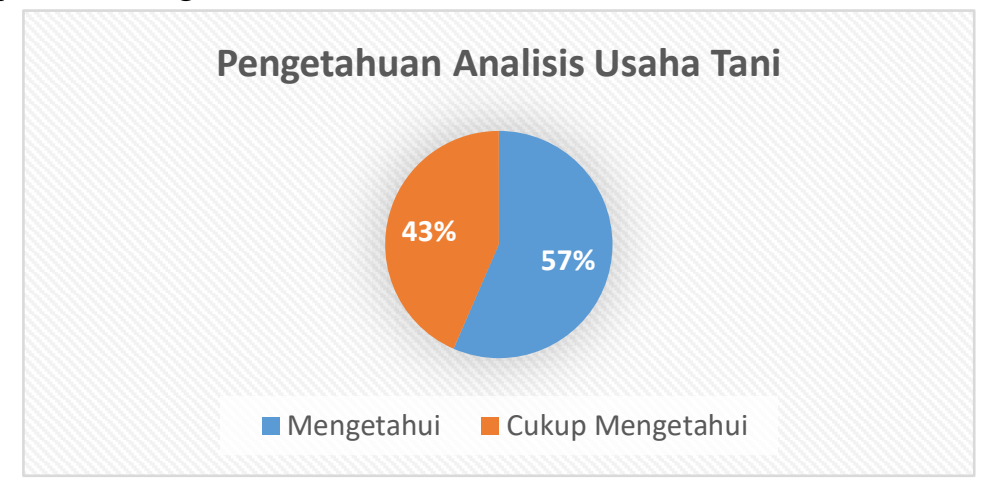

Gambar 3. Pengetahuan Mitra tentang Analisis Usaha Tani Jagung

Berdasarkan analisis data diketahui bahwa tingkat pengetahuan petani mengenai analisis usaha tani mengalami peningkatan yaitu $43 \%$ cukup mengetahui dan 57\% mengetahui. Setelah mengikuti kegiatan ini, peserta mendapatkan tambahan pengetahuan mengenai biaya usaha tani. Kegiatan ini juga memberikan informasi kepada petani mengenai analisis kelayakan usaha tani agar layak untuk dikembangkan di masa depan. Analisis kelayakan usaha tani menggunakan analisis $\mathrm{R} / \mathrm{C}$ rasio dimana usaha tani dikatakan efisien ketika rasio output terhadap inputnya bernilai lebih dari satu.

Capaian kegiatan adalah teknologi mesin yang dimiliki oleh petani mampu mengurangi tingkat ketergantungan biaya dan sarana produksi ke pedagang. Penyuluhan analisis usaha tani mampu memberikan informasi kepada petani tentang usaha tani yang memberikan keuntungan, impas, atau merugi.

Pelaksanaan monitoring dilakukan selama kegiatan berlangsung. Monitoring dilakukan pada saat kelompok tani menggunakan mesin pasca panen dan ketika kelompok tani mengisi kuesioner. Hambatan teknis pada saat mengoperasikan mesin adalah ketika petani tidak memperhatikan kemampuan mesin sehingga perlu kontrol dari tim agar mesin dapat berfungsi dengan baik. Pada saat petani mengisi kuesioner terdapat petani yang belum paham mengenai biaya-biaya yang dimaksud, sehingga perlu bantuan dari tim untuk membantu petani mengisi kuesioner. Kesulitan kegiatan juga terdapat pada komunikasi dengan anggota kelompok tani. Terdapat petani yang jarang berinteraksi membahas mengenai analisis usaha tani. Keterbatasan aktivitas komunikasi memiliki hubungan dengan tingkat pengetahuan (Mukhlishah dkk, 2014). Sehingga hal ini menjadi salah satu faktor yang menghambat meningkatnya pengetahuan petani. Kedepannya diharapkan analisis usaha tani menjadi bahan komunikasi diantara anggota kelompok tani. 
Kegiatan evaluasi juga dilakukan kepada mitra petani. Evaluasi kegiatan dilakukan setelah kegiatan pelatihan dan penyuluhan dilaksanakan. Hasil evaluasi menunjukkan bahwa manajemen organisasi kelompok tani belum maksimal mengelola mesin pasca panen sehingga menimbulkan masalah yaitu adanya pihak tertentu yang ingin menguasai mesin tersebut. Solusi yang diberikan adalah dengan membuat fakta integritas yang mengatur penggunaan mesin. Hasil evaluasi juga menunjukkan pengetahuan petani yang masih rendah tentang kadar air jagung dan tongkolnya sebelum dimasukkan di mesin. Solusi yang diberikan adalah memberi informasi bahwa jagung dan tongkol sebaiknya dijemur atau dikeringkan dahulu sebelum dimasukkan didalam mesin. Temuan penting lainnya adalah terdapat petani yang masih belum mau mencatat biaya-biaya yang telah mereka keluarkan, sehingga diperlukan motivasi lanjutan agar anggota kelompok tani rutin menghitung analisis usaha taninya.

\section{Kesimpulan}

Kegiatan penyuluhan telah dilaksanakan dan berjalan dengan baik. Kegiatan ini juga direspon positif oleh petani jagung. Kegiatan ini telah memberikan pemahaman baru bagi petani tentang penggunaan mesin multi fungsi dan analisis usaha tani. Berdasarkan hasil analisis data diketahui terjadi peningkatan pengetahuan analisis usaha tani. Pada kelanjutan dari kegiatan ini diharapkan mitra petani mampu mencatat dengan baik segala biaya yang dikeluarkan dan biaya yang masuk hasil dari usaha tani. Sehingga catatan usaha tani dapat dijadikan acuan dan informasi kelayakan usaha taninya.

\section{Ucapan Terimakasih}

Ucapan terima kasih yang sebesar-besarnya disampaikan pada Badan Riset dan Inovasi Nasional (BRIN) Republik Indonesia selaku penyandang dana dari kegiatan ini, dan Lembaga Penelitian dan Pengabdian Masyarakat (LPPM) Universitas Indonesia Timur, Makassar.

\section{Daftar Pustaka}

Athaillah, T. (2020). Pembukuan Usaha Tani Padi Di Desa Leuhan Kecamatan Johan Pahlawan Kabupaten Aceh Barat. Jurnal Abdimas Bina Bangsa, 1(1), 80-86.

Berliana, R. B. T. (2010). Analisis Efisiensi Produksi Dan Pendapatan Pada Usahatani Jagung Di Kecamatan Wirosari, Kabupaten Grobongan (Studi Kasus: Di Desa Tambahrejo Dan Desa Tambahselo). Skripsi. Universitas Diponegoro.

Damayanti, U., \& Herdian, D. (2016). Analisis Harga pokok Dan Keuntungan Usahatani Cabai Merah Besar (Capsicum Annuum L) Di Desa Talang Buluh Kecamatan Talang Kelapa Kabupaten Banyuasin. Jurnal TriAgro, 1(2). 
Dinas Tanaman Pangan, Holtikultura, Perkebunan. (2020). Angka Tetap Luas Panen, Produktifitas, dan Produksi Jagung Tahun 2020 Provinsi Sulawesi Selatan. Makassar.

Harmono, S. T. P., \& Andoko, A. (2005). Budi Daya \& Peluang Bisnis Jahe. AgroMedia.

Jaya, M. D. P. (2016). Analisis Perbandingan Pendapatan Petani Padi Sawah Menggunakan Mesin Combine Hervester Dengan Cara Tradisional Di Gampong Blang.

Mukhlis, M., \& Suyono, A. (2013). Analisis Penawaran dan Permintaan Jagung untuk Pakan Ayam Ras di Kabupaten Lima Puluh Kota.

Mukhlishah, N., Saleh, A., \& Sadono, D. (2014). Aktivitas Komunikasi Organisasi dan Kinerja Pendamping dalam Program Gernas Kakao di Kabupaten Polewali Mandar. Jurnal Komunikasi Pembangunan, 12(2).

Normansyah, D., Rochaeni, S., \& Humaerah, A. D. (2014). Analisis Pendapatan Usahatani Sayuran di Kelompok Tani Jaya, Desa Ciaruteun Ilir, Kecamatan Cibungbulang, Kabupaten Bogor. Agribusiness Journal, 8(1), 29-44.

Risal, D., \& Rahmawati, R. (2021). Diseminasi Mesin Teknologi Multifungsi untuk Meningkatkan Kualitas Produksi Jagung dan Limbahnya. JATI EMAS (Jurnal Aplikasi Teknik dan Pengabdian Masyarakat), 5(3), 119124.

Sundari, M. T. (2011). Analisis Biaya dan Pendapatan Usaha Tani Wortel Di Kabupaten Karanganyar. SEPA: Jurnal Sosial Ekonomi Pertanian dan Agribisnis, 7(2).

Soekartawi. (2005). Analisis Usahatani. PT. Raja Grafindo Persada. Jakarta.

Umar, S. (2011). Teknologi Alat dan Mesin Pasca Panen Sebagai Komponen Pendukung Usahatani Jagung di Lahan Kering Kalimantan Selatan. Jurnal Agrista, 15(3), 109-116. 